\title{
ECOBRICKS, DAUR ULANG SAMPAH PLASTIK SEBAGAI RINTISAN ECOPRENEURSHIP
}

\author{
L.V. Ratna Devi Sakuntalawati1,3, Irsyadul Ibad ${ }^{2,3}$ \\ ${ }^{1}$ Sosiologi, FISIP, Universitas Sebelas Maret, Jl. Ir. Sutami No 36A, Surakarta, 57126, Indonesia \\ ${ }^{2}$ D3 Manajemen Administrasi, Sekolah Vokasi, Universitas Sebelas Maret, Jl. Ir. Sutami No 36A, \\ Surakarta, 57126, Indonesia \\ 3Pusat Pengembangan Kewirausahaan LPPM Universitas Sebelas Maret, Jl. Ir. Sutami No 36A, \\ Surakarta, 57126, Indonesia
}

Email: ratnadevi.solo@staff.uns.ac.id

\begin{abstract}
ABSTRAK
Kegiatan pengelolaan sampah rumah tangga di bank sampah ini masih sebatas pengumpulan, pemilahan, penimbangan, pencatatan, dan penjualan. Salah satu jenis sampah rumah tangga yang paling banyak dihasilkan adalah sampah plastik, tetapi sebagian besar hanya dijual ke pengepul. Hal ini menunjukkan bahwa pengelolaan sampah plastik menjadi produk kreatif belum dikembangkan. Padahal, jika menjadi produk kreatif akan meningkatkan nilai ekonomis sampah plastik tersebut. Oleh karena itu, Bank Sampah diberikan pelatihan dan pendampingan produk kreatif berupa material produk kreatif dengan teknologi ecobricks dan pemasaran produk kreatif. Hasilnya mitra mampu melakukan pengolahan sampah plastik menjadi material yang selanjutnya dikreasikan menjadi produk kreatif berupa set furnitur stool dan meja. Selain itu, produk ini mampu menyerap sampah plastik sebanyak lebih kurang $25 \mathrm{~kg}$ sehingga teknologi tepat guna ecobricks ini sangat cocok untuk mengurangi timbunan sampah plastik yang dihasilkan oleh rumah tangga. Untuk keberlanjutan kegiatan usaha bank sampah, dilakukan pendampingan sejak awal sampai pasca program kemitraan masyarakat. Hal ini bertujuan agar bank sampah dapat berfungsi sebagai pusat kegiatan yang menjadi wadah usaha yang kegiatannya termasuk daur ulang sampah plastik menjadi produk kreatif. Kegiatan ini dapat menjadi rintisan ecopreneurship yang diharapkan dapat memenuhi permintaan pasar dan meningkatkan pendapatan masyarakat.
\end{abstract}

Kata Kunci: bank sampah, sampah plastik, ecobricks, stool, ecopreneurship.

\begin{abstract}
Sejahtera Waste Bank is a waste bank located in $5^{\text {th }}$ hamlet, Joyotakan Village, Serengan District, Surakarta City. Household waste management activities in this waste bank are still limited to collecting, sorting, weighing, recording, and selling. Plastic waste is one of the most common types of household waste, but most of it is only sold to collectors.
\end{abstract}


It shows that the management of plastic waste into creative products has not been developed. In fact, if it becomes a creative product, it will increase the economic value of the plastic waste. Therefore, the Waste Bank is given training and assistance for creative products in the form of creative product materials with ecobricks technology and creative product marketing. As a result, partners are able to process plastic waste into material which is then created into creative products in the form of stool and table furniture sets. In addition, this product is capable of absorbing approximately $25 \mathrm{~kg}$ of plastic waste, so using ecobricks technology is very suitable for reducing piles of plastic waste generated by households. For the sustainability of the waste bank business activities, assistance is carried out from the beginning to the end of the community partnership program. It is intended that the waste bank can function as a center for activities that become a place for businesses whose activities include recycling plastic waste into creative products. This activity can be an ecopreneurship pilot that is expected to meet market demand and increase people's income.

Keywords: waste bank, plastic waste, ecobricks, stool, ecopreneurship.

\section{PENDAHULUAN}

Terdapat \pm 75 bank sampah di kota Surakarta. Tidak semua dari mereka ini melakukan pengolahan sampah menjadi produk kreatif. Hanya terdapat $12,5 \%$ bank sampah dari seluruh bank sampah yang berpartisipasi (Vigintan et al., 2019). Dengan kata lain masih banyak bank sampah yang belum mengelolanya. Padahal sudah diakui oleh $12,5 \%$ bank sampah tersebut bahwa ada peningkatan pendapatan. Bank sampah-bank sampah yang belum mengelola sampah menjadi produk kreatif, hanya melakukan 5 hal dalam pengelolaan sampah, yaitu mengumpulkan, memilah, menimbang, mencatat dan menjual. Pada kegiatan menjual, setiap jenis sampah, memiliki harga jual yang berbeda-beda. Jenis sampah yang dikumpulkan oleh bank sampah, adalah sampah rumah tangga yang kebanyakan adalah berjenis plastik, terutama plastik kemasan. Hal ini seperti yang dinyatakan oleh Statistik Lingkungan Hidup Indonesia tahun
2018, bahwa $14 \%$ dari 64 juta ton sampah/tahun, yaitu \pm 9 juta ton adalah sampah plastik (plastik sekali pakai seperti kemasan dan kantong plastik) (Purwaningrum, 2016). Adapun harga jual sampah plastik, per kilogram Rp. 700,- dan dijual kepada pengepul. Padahal jika didaur ulang akan meningkatkan nilai jual.

Bank sampah Sejahtera yang berada di RW 5 Kelurahan Joyotakan, Kecamatan Serengan, Kota Surakarta, adalah salah satu bank sampah yang sudah berkegiatan mengelola sampah non organik dari rumah tangga warga sampai pada penjualan sampah saja, dan belum mengolah sampah menjadi produk kreatif. Mengingat banyaknya sampah plastik dan tidak memiliki nilai jual yang layak, maka hal ini menjadi permasalahan jika pengelolaan sampah tersebut menjadi agenda yang bertujuan untuk meningkatkan pendapatan. Adapun tujuan pengabdian adalah pengelolaan sampah plastik menjadi produk kreatif yang mampu memberi nilai ekonomis sampah plastik. 
Untuk

meningkatkan

pendapatan, maka masyarakat harus berdaya, salah satunya dapat dilakukan dengan Program Kemitraan Masyarakat. Dalam program ini terkandung proses pemberdayaan masyarakat yang terkait erat dengan faktor internal dan eksternal (Hamid, 2018). Faktor eksternal adalah tim pendamping yang berperan mendorong masyarakat untuk berdaya. Faktor internal adalah masyarakat yang langsung terlibat dan melaksanakan kegiatan. Pada awal kegiatan peran tim pendamping sangat aktif, tetapi dengan berjalannya waktu peran itu akan berkurang seiring dengan mandirinya masyarakat dalam berkegiatan. Hal ini sangat sesuai dengan implementasi program pembangunan yang mengarah kepada pencapaian upaya pembangunan yang berpusat pada manusia (people centered development) (Mahadiansar et al., 2020).

Peran tim pendamping sesuai adalah melakukan kegiatan pencairan diri dengan masyarakat sasaran, menggerakkan masyarakat melakukan perubahan dan pemantapan hubungan dengan masyarakat (Purwowibowo et al., 2018). Dalam menggerakkan masyarakat kegiatan mendiagnosis kebutuhan sangatlah penting. Selanjutnya menganalisis tentang motivasi, sumber daya yang tersedia dan kemampuan masyarakat. Terakhir memilih obyek perubahan yang paling tepat (Hamid, 2018). Dalam hal ini tim pendamping bersama bank sampah Sejahtera memilih metode Ecobrik sebagai obyek perubahan yang tepat dalam rangka peningkatan pendapatan yaitu dengan menambah nilai jual sampah plastik.

Ecobricks merujuk kepada metode yang digunakan untuk mengurangi sampah plastik dengan menggunakan media botol plastik yang diisi penuh dengan sampah non organik yang sudah dibersihkan hingga botol tersebut menjadi keras dan padat (Andriastuti et al., 2019) Selanjutnya, botol-botol tersebut dapat dijadikan sesuatu yang berguna seperti meja, kursi, tembok, pagar maupun pot tanaman. Bahan-bahan yang diperlukan terdiri dari sampah, yaitu botol plastik, sampah plastik dan tongkat kayu. Setiap botol diisi 1/3 (sepertiga) volume botol. Jika botol bervolume $600 \mathrm{ml}$, maka sampah yang diperlukan 200-250 gram. Teknologi ecobricks menghasilkan material produk kreatif (Sukimto \& Sekartaji, 2017).

Untuk mendapatkan nilai jual yang layak, dilakukan dengan cara merangkai material produk kreatif menjadi sebuah benda yang layak jual. Bank sampah Sejahtera memilih membuat satu set furnitur berupa stool dan meja. Kegiatan ini merupakan rintisan usaha atau dapat dikatakan rintisan ecopreneurship. Untuk memantabkan hubungan dengan masyarakat, tim pendamping melakukan pelatihan Etika Organisasi. Pelatihan ini untuk menyadarkan bank sampah Sejahtera, bahwa mereka memiliki peran penting dalam mengelola sampah rumah tangga (Rahmadani, 2020). Bank sampah dapat menjadi wadah awal untuk membentuk kesadaran masyarakat secara kolektif dalam memilah, mendaur-ulang, dan memanfaatkan sampah. Hal ini bertujuan agar 
sampah mempunyai nilai ekonomis dan menggalakkan budaya baru dalam pengelolaan sampah yang berwawasan lingkungan (Suryani, 2014). Selain itu sebagai suatu organisasi harus dapat menunjukkan pada anggotanya bahwa melakukan kegiatan bisnis itu baik, asal memberikan manfaat bagi orang banyak, terutama anggota organisasi. Hal ini sesuai dengan teori utilitarianisme Jeremy Benthan. Teori utilitarianisme termasuk teori etika kegunaan (utility) suatu tindakan ekonomi (Latipulhayat, 2015). Kegiatan menyadarkan bank sampah atau menumbuhkan kedasaran (sikap), diharapkan mampu mengubah perilaku anggota bank sampah (Hamid, 2018) dalam mengelola sampah menjadi produk kreatif.

Selain pelatihan Etika Organisasi diberikan juga pelatihan Pemasaran. Pelatihan ini bertujuan untuk memberi pengetahuan tentang teknik menjual dan menentukan harga jual produk kreatif. Penetapan harga jual produk sangat penting karena produk kreatif ini biasanya memiliki persaingan harga jual yang lebih ketat karena konsumen akan membandingkan dengan harga produk baru (Yuliarini, 2020). Dalam kasus ini, penghitungan harga pokok produksi yang matang akan berguna untuk menentukan harga jual yang akurat, sehingga produk tersebut dapat bersaing dengan produk lain dipasaran (Mariani et al., 2014). Strategi penentuan harga jual dengan menggunakan teknik harga pokok produksi adalah dengan memasukkan seluruh komponen biaya produksi sebagai unsur harga pokok yang terdiri dari biaya bahan baku, biaya tenaga kerja langsung, biaya overhead (variabel maupun tetap) ditambah dengan biaya non produksi. Metode ini merupakan metode full costing yang digunakan untuk memecahkan masalah dalam penentuan harga produk kreatif sampah ecobricks (Fitriani and Asih, 2019). Dalam proses pengembangan produk olahan sampah, Bank Sampah perlu melakukan pemasaran produk. Pemasaran ini digunakan untuk menginformasikan konsumen mengenai produk serta meyakinkan konsumen mengenai kemampuan produk dalam memuaskan kebutuhan dan keinginan konsumen (Rozalena, 2020). Adapun pemasaran produk akan berfokus kepada marketing mix (Suhelpi and Saragih, 2020), yakni Product, Price, Place dan Promotion, dimana satu dengan yang lain saling berhubungan. Setelah semua pelatihan dilakukan, selanjutnya memonitor keberlanjutan kegiatan program kemitraan masyarakat yang ada di Bank Sampah Sejahtera.

\section{METODE}

Kegiatan awal dilakukan dengan identifikasi permasalahan mitra, menggunakan metode diskusi (FGD). Hasil identifikasi kemudian digunakan sebagai acuan rumusan alternatif pemecahan masalah mitra. Solusi pemecahan tersebut kemudian diaplikasikan di lapangan. Selama pengaplikasian di lapangan, mitra dimonitor (dipantau) melalui kegiatan pendampingan usaha sampai mitra dapat menerapkan ilmu yang diperoleh dari pelatihan. 
Prosedur kerja yang dilakukan untuk memecahkan permasalahan yang dihadapi mitra yaitu:

1. Peningkatan Pengetahuan

Peningkatan pengetahuan dilakukan kepada anggota dan pengurus Bank Sampah Sejahtera. Peningkatan pengetahuan ini dilakukan melalui kegiatan pelatihan, baik pelatihan inclass maupun outclass, antara lain:

a. Pelatihan Etika Organisasi

Pelatihan mengenai etika organisasi Bank Sampah Sejahtera sebagai agen perubahan sosial terutama dalam hal pengelolaan sampah.

b. Pelatihan Pembuatan ecobricks dan Produk Kreatif

Pelatihan pembuatan ecobricks menggunakan bahan dasar botol air mineral bekas dan sampah plastik kemasan dan kantong yang selanjutnya akan dibuat menjadi produk kreatif.

c. Pelatihan Pemasaran Produk

Kreatif

Pelatihan ini terkait dengan bagaimana cara Bank Sampah Sejahtera dapat menentukan harga jual produk kreatif ecobricks dan platform pemasaran apa yang sesuai untuk menjual produk tersebut.

2. Pemberian Teknologi Tepat Guna

Teknologi tepat guna yang diberikan kepada mitra berupa ecobricks sebagai material produk kreatif.

3. Monitoring Rintisan Ecopreneurship

Monitoring ini dilakukan untuk mengetahui tingkat penerapan kegiatan.

\section{HASIL DAN PEMBAHASAN}

\subsection{Hasil Pelaksanaan PKM}

\subsubsection{Hasil FGD tentang identifikasi} permasalahan mitra

FGD dilakukan agar rancangan program kegiatan pelatihan maupun pendampingan kepada mitra dapat tepat sasaran. Adapun hasil yang diperoleh sebagai berikut:

1) Kegiatan pengelolaan sampah rumah tangga yang dilakukan oleh Bank Sampah Sejahtera hanya sebatas pengumpulan, pemilahan, penimbangan, pencatatan dan penjualan ke pengepul sehingga belum ditemui adanya pengelolaan sampah menjadi produk kreatif untuk dapat meningkatkan nilai ekonomis sampah rumah tangga. Oleh karena itu, perlu adanya sebuah kegiatan daur ulang sampah rumah tangga menjadi produk kreatif.

2) Rencana kegiatan yang akan dilaksanakan

a) Pelatihan outclass serta pendampingan pembuatan ecobricks dan produk kreatif

b) Pelatihan inclass etika organisasi Bank Sampah dan pemasaran produk kreatif

c) Pelatihan teknologi tepat guna (TTG) berupa ecobricks sebagai material produk kreatif.

\subsubsection{Hasil Pelatihan Etika Organisasi}

Pelatihan inclass Etika Organisasi diberikan sebagai upaya untuk meningkatkan pengetahuan dan kesadaran para anggota Bank Sampah. Materi pelatihan dimulai dengan pemaparan mengenai pentingnya menjaga lingkungan hidup yang 
bersih dan sehat terutama dari adanya penumpukan sampah. Jenis-jenis sampah beserta waktu terurainya juga dipaparkan supaya masyarakat dapat mengurangi konsumsi produk-produk yang dapat menghasilkan sampahsampah yang susah terurai tersebut. Upaya Bank Sampah yang dapat berperan sebagai wadah perubahan sosial dan anggota Bank Sampah sebagai agennya. Peran sebagai agen perubahan sosial dapat dimulai dengan memfungsikan Bank Sampah dalam mendukung pengelolaan sampah rumah tangga sesuai dengan konsep 3R (Reduce, Reuse, and Recycle). Harapannya adalah agar tercipta lingkungan yang bersih dan sehat. Selain itu, dengan struktur organisasi Bank Sampah yang sudah terbentuk maka pengelolaan sampah rumah tangga juga dapat diarahkan untuk peningkatan pendapatan melalui daur ulang sampah rumah tangga menjadi produk kreatif khusunya sampah plastik karena jenis sampah ini dapat dikreasikan menjadi berbagai macam produk kreatif yang dapat dijual ke pasaran. Anggota Bank Sampah dipecah menjadi empat kelompok daur ulang.

\subsubsection{Hasil Pelatihan Pembuatan Ecobricks dan Produk Kreatif}

Pelatihan diberikan kepada anggota Bank Sampah Sejahtera yang berjumlah 20 orang. Materi pelatihan berisi penjelasan mengenai definisi ecobricks, tujuan ecobricks, pemanfaatan ecobricks, cara pembuatan ecobricks, bentuk ecobricks beserta cara pemasangannya. Cara pembuatan ecobricks dimulai dengan menyiapkan botol plastik kosong ukuran $1500 \mathrm{ml}$ atau $600 \mathrm{ml}$ atau ukuran apa saja asal seragam. Kemudian, siapkan sampah plastik yang dapat berupa plastik kemasan, kantong plastik, sedotan dan lain-lain serta tongkat kayu atau bambu dengan diameter $\pm 6 \mathrm{~mm}$ dengan panjang minimal 2 kali tinggi botol plastik. Sampah plastik dimasukkan ke dalam botol lalu dipadatkan dengan menggunakan tongkat kayu/bambu. Lakukan hingga botol plastik mencapai berat standar (500 gr untuk botol ukuran $1500 \mathrm{ml}$ ). Berat ecobricks minimal adalah sepertiga dari ukuran botol (dalam gram). Ada tiga jenis sampah rumah tangga yang tidak bisa digunakan dalam ecobricks yaitu sampah kertas, kaca, dan logam. Secara umum, bentuk ecobricks ada tiga macam antara lain: 1 ). Triangle Milsten Module, yaitu ecobricks yang terdiri dari 12 buah dan berbentuk menyerupai segitiga;2). Hexagon Milsten Module, yaitu ecobricks yang terdiri dari 19 buah dan berbentuk menyerupai segi delapan; 3 ) Dieleman Lego Module, yaitu ecobricks yang terdiri dari 16 buah dan berbentuk menyerupai persegi panjang. Setelah botol-botol terisi sampah plastik dan menjadi padat maka botol ditimbang untuk mengecek kesesuaian berat botol dengan berat minimal ecobricks. Hal ini untuk memastikan ketahanan ecobricks apabila nanti akan digunakan sebagai produk kreatif berupa meja atau kursi. Kemudian, botol-botol yang sudah siap diletakkan pada permukaan yang rata. Selanjutnya, botol-botol dicek kembali untuk memastikan ukurannya sama. Kemudian, pola warna botolbotol tersebut dapat dibuat berdasarkan tutup dan dasar botol. Titik-titik pertemuan antar botol 
kemudian direkatkan dengan menggunakan lem tembak. Tekan agar menempel. Biarkan agar mengering selama 24 jam. Selain itu, dapat juga menggunakan lakban bening yang direkatkan secara memutar dari atas sampai bawah. Jika menggunakan botol-botol dari merek yang sama, bagian atas modul segi enamakan klop dengan bagian bawah modul segitiga. Apabila sudah selesai direkatkan sesuai bentuk dan fungsi yang diinginkan maka ecobricks dapat dikreasikan sesuai dengan kreatifitas anggota Bank Sampah. Dari pelatihan ini, setiap kelompok dapat membuat 19 ecobricks.

\subsubsection{Hasil Pelatihan Pemasaran Produk Kreatif}

Pembuatan satu set furniture yang terdiri dari 4 stool dan 1 meja memerlukan 95 ecobricks. Untuk satu stool, dibuat dari susunan 19 ecobricks ukuran $600 \mathrm{ml}$ sedangkan untuk meja disusun dari 19 ecobricks ukuran 1,5 liter. Susunan ecobricks kemudian direkatkan dengan menggunakan lakban bening secara melingkar dari bawah sampai atas sehingga posisi ecobricks akan simetris dan dapat berdiri dengan sempurna. Kemudian di atasnya akan diletakkan triplek yang sudah dipotong sesuai ukuran stool dan diberikan bantalan busa bekas sebagai alas duduk kemudian direkatkan dengan menggunakan lem fox agar dapat menempel secara kuat dengan susunan ecobricks di bawahnya. Dari pelatihan ini, setiap kelompok mampu menghasilkan satu stool dan satu meja yang dikerjakan secara bersama-sama. Selain itu, dalam pelatihan ini, mitra diberikan pengetahuan untuk menentukan harga produk kreatif ecobricks sebelum kemudian dapat dipasarkan melalui platform digital. Strategi penentuan harga yang digunakan adalah metode full costing, dimana harga jual produk dihitung dengan menentukan terlebih dahulu harga pokok produksinya. Setiap komponen biaya produksi yang terdiri dari biaya bahan baku, biaya tenaga kerja langsung dan biaya overhead akan dihitung untuk mengetahui harga pokok produksi.

Biaya-biaya yang digunakan untuk menentukan harga pokok produksi menggunakan metode full costing adalah sebagai berikut:

a) Biaya Bahan Baku

\begin{tabular}{ccccc}
$\begin{array}{c}\text { Tabel 1. } \\
\text { Ecobricks }\end{array}$ & Biaya & Bahan & Baku & Stool \\
\hline $\begin{array}{c}\text { Bahan } \\
\text { Baku }\end{array}$ & Harga & $\begin{array}{c}\text { Jumlah } \\
\text { Unit }\end{array}$ & Satuan & $\begin{array}{c}\text { Total } \\
\text { Biaya }\end{array}$ \\
\hline $\begin{array}{c}\text { Botol } \\
\text { plastik }\end{array}$ & 300 & 19 & buah & 5700 \\
$\begin{array}{c}\text { Sampah } \\
\text { plastik } \\
\text { Lem } \\
\text { Bahan }\end{array}$ & 700 & 4 & $\mathrm{~kg}$ & 2800 \\
Pembantu & 10000 & 1 & buah & 5000 \\
\hline Total & & & paket & 10000 \\
\hline
\end{tabular}

Tabel 2. Biaya Bahan Baku Meja Ecobricks

\begin{tabular}{ccccc}
\hline $\begin{array}{c}\text { Bahan } \\
\text { Baku }\end{array}$ & Harga & $\begin{array}{c}\text { Jumlah } \\
\text { Unit }\end{array}$ & Satuan & $\begin{array}{c}\text { Total } \\
\text { Biaya }\end{array}$ \\
\hline $\begin{array}{c}\text { Botol } \\
\text { plastik }\end{array}$ & 500 & 19 & buah & 9500 \\
$1500 \mathrm{ml}$ & & & & \\
$\begin{array}{c}\text { Sampah } \\
\text { plastik } \\
\text { Lem }\end{array}$ & 700 & 9,5 & $\mathrm{~kg}$ & 6650 \\
$\begin{array}{c}\text { Bahan } \\
\text { pembantu }\end{array}$ & 10000 & 1 & buah & 7000 \\
\hline Total & & 1 & paket & 10000 \\
\hline
\end{tabular}


b) Biaya tenaga kerja langsung

Upah tenaga kerja langsung adalah biaya yang dikeluarkan untuk membayar anggota Bank Sampah yang terlibat langsung pada pembuatan produk kreatif. Besarnya upah tenaga kerja langsung sebesar Rp 1.000 per botol ecobrick $600 \mathrm{ml}$, sehingga apabila setiap satu kursi kreasi ecobrick memerlukan 19 unit ecobrick, maka total biaya tenaga kerja langsung sebesar Rp. 19.000, sedangkan untuk meja yang menggunakan 19 ecobrick 1,5 liter, upah tenaga kerjanya sebesar Rp. 2.000 per botol ecobrick maka total biaya tenaga kerja langsungnya sebesar Rp. 38.000.

c) Biaya Overhead

Biaya overhead adalah biaya tambahan atau biaya lain-lain, yang tidak terkait langsung dengan proses bisnis dan produksi yang dilakukan. Dalam produk kreatif ini, biaya overhead berhubungan dengan pembelian alat seperti gunting pencacah, tongkat kayu, dan juga gergaji kayu. Misalnya: estimasi biaya overhead sebesar 10\% maka biaya overhead dapat dihitung sebagai berikut:

Tabel 3. Biaya Overhead Stool dan Meja Ecobricks

\begin{tabular}{cccc}
\hline Uraian & Harga & Estimasi & $\begin{array}{c}\text { Total } \\
\text { Biaya }\end{array}$ \\
\hline $\begin{array}{c}\text { Gunting } \\
\text { Tongkat } \\
\text { kayu }\end{array}$ & 10.000 & $10 \%$ & 1000 \\
$\begin{array}{c}\text { Gergaji } \\
\text { Kayu }\end{array}$ & 20.000 & $10 \%$ & 1000 \\
\hline Total & $10 \%$ & 2000 \\
\hline
\end{tabular}

Setelah mengidentifikasi biayabiaya yang terkait, selanjutnya besaran harga pokok produksi satu set furniture ecobricks dengan pendekatan metode full costing adalah sebagai berikut.

Tabel 4. Harga Pokok Produksi Stool Ecobricks

\begin{tabular}{cc}
\hline Uraian & Besaran \\
\hline Biaya Bahan Baku & 23500 \\
Biaya Tenaga Kerja & 19000 \\
Langsung & \\
Biaya Overhead & 4000 \\
\hline Total & 46500 \\
\hline
\end{tabular}

Tabel 5. Harga Pokok Produksi Meja

\begin{tabular}{cc}
\hline Uraian & Besaran \\
\hline Biaya Bahan Baku & 33150 \\
Biaya Tenaga Kerja & 38000 \\
Langsung & \\
Biaya Overhead & 4000 \\
\hline Total & 75150 \\
\hline
\end{tabular}

Langkah selanjutnya adalah pengurus Bank Sampah Sejahtera dapat menentukan harga jual stool dan meja ecobricks sesuai yang mereka inginkan. Harga jual dapat ditentukan dengan menentukan berapa persen keuntungan yang mereka ingin dapatkan sebagai margin penentuan harga jual.

Selain itu, pelatihan tentang promosi produk kreatif juga diberikan kepada anggota Bank Sampah. Dikarenakan masih merupakan rintisan ecopreneurship maka Bank Sampah Sejahtera menyepakati bahwa media promosi yang digunakan dalam promosi produk kreatif set furnitur stool dan meja dari ecobricks akan dipromosikan melalui media sosial whatsapp grup. Whatsapp grup ini berisi perangkat Kelurahan Joyotakan dan masyarakat sekitar yang dinamakan Joyotakan Jaya. 


\subsubsection{Hasil Pelatihan Penggunaan Teknologi Tepat Guna}

Pelatihan penggunaan TTG berupa ecobricks sebagai material produk kreatif di awali dengan pembuatan ecobricks oleh para anggota Bank Sampah. Ecobricks yang akan digunakan sebagai material stool menggunakan botol plastik $600 \mathrm{ml}$ sedangkan ecobricks yang digunakan sebagai material meja menggunakan botol plastik $1500 \mathrm{ml}$. Botol-botol tersebut akan diisi sampah plastik sesuai berat minimal ecobricks kemudian direkatkan membentuk pola tertentu dan disesuaikan dengan fungsi produk kreatif yang akan dihasilkan.

\subsubsection{Hasil Monitoring Rintisan Ecopreneurship}

Dari keseluruhan proses pelatihan dan pendampingan, para anggota Bank Sampah mampu menghasilkan satu set furnitur yang terdiri dari empat stool dan sebuah meja ecobricks. Setelah itu produk tersebut dikreasikan untuk menambah nilai jualnya dan dipromosikan melalui whatsapp grup Joyotakan Jaya sebagai rintisan awal ecopreneurship.

\subsection{Pembahasan}

Bank sampah Sejahtera sebagai pengelola sampah rumah tangga telah melakukan kegiatan untuk meningkatkan pendapatan, melalui program " $5 \mathrm{P}$ " (pengumpulan, pemilahan, penimbangan, pencatatan, penjualan). Akan tetapi peningkatan tersebut belum memanfaatkan sampah dengan konsep "3R" (Reduce, Reuse, Recycle). Melalui program " $5 \mathrm{P}^{\prime}$ harga sampah, terkategori rendah, terutama sampah plastik (plastik kemasan maupun kantong). Jika melakukan "3R"dalam pengelolaan sampah plastik, akan memberikan nilai tambah pada produk kreatif. Konsep " $3 R^{\prime \prime}$ diterapkan dalam teknik ecobrik, yaitu mampu mengurangi (reduce) sampah karena sampah dimasukkan botol plastik yang merupakan proses recycle menjadi material produk kreatif, selanjutnya dapat digunakan untuk memproduk barang kreatif dan jika nilai gunanya menurun, reuse barang kreatif lain. Syarat untuk dapat mengolah sampah menjadi produk kreatif, bank sampah harus berdaya. Disini perlu ada yang memberdayakan dengan program pemberdayaan. Program Kemitraan Masyarakat menjadi pilihan bank sampah Sejahtera untuk bermitra dengan tim pemberdaya. Tiga kegiatan pemberdayaan yang dilakukan oleh tim pemberdaya, yaitu pelatihan Etika Organisasi, pelatihan Pembuatan ecobricks dan Produk Kreatif, pelatihan Pemasaran Produk Kreatif. Semua pelatihan ini adalah tahapan proses pemberdayaan masyarakat. Pelatihan Etika organisasi, adalah penyadaran akan peran bank sampah dalam pengelolaan sampah rumah tangga di wilayahnya. Ini merupakan tahap penyadaran. Pelatihan pembuatan material produk kreatif dengan teknik ecobrik, merupakan pemberdayaan dengan menerapkan ide kreatifitas. Tahap ini adalah tahap membantu memecahkan masalah. Pelatihan pemasaran produk kreatif merupakan pengetahuan untuk melakukan tahapan pengujian dan demonstrasi. Pada tahap ini produk yang telah dibuat ditentukan harga jualnya, meletakkan produk di social media (WA 
grup Joyotakan Jaya) dan mempromosikan kepada seluruh warga Joyotakan. Pelaksanaan pelatihan ini, telah sesusai dengan konsep pemberdayaan, yaitu menekankan pada proses pemberian kemampuan dan memotivasi agar bank sampah berdaya. Jika Bank Sampah Sejahtera berdaya dalam mengolah sampah menjadi produk kreatif, itu berati mampu memberi nilai tambah berupa harga yang lebih layak pada sampah yang menjadi produk kreatif. Produk Kreatif dari sampah plastik ini yang menjadi rintisan ecopreneurship. Usaha ini merupakan cara anggota bank sampah dapat meningkatkan pendapatan. Peningkatan pendapatan adalah salah satu upaya mencapai peningkatan taraf hidup. Ini sesuai dengan pendekatan pembangunan yang berpusat pada manusia (people centered development), yaitu pada upaya meningkatkan taraf hidup masyarakat yang berfokus pada pemberdayaan dan pembangunan manusia itu sendiri.

\section{KESIMPULAN}

Upaya Bank Sampah Sejahtera dalam mewujudkan produk kreatif dengan tehnik Ecobrik sebagai rintisan ecopreneurship

Melalui metode FGD, telah ditemukan permasalahan pengolahan sampah plastik, sekaligus diputuskan memberi nilai tambah pada sampah plastik. Selain itu diputuskan juga mengikuti program Kemitraan Masyarakat dengan cara bermitra. Dalam program ini diterapkan tahapan proses pemberdayaan yang berwujud pelatihan pendampingan yaitu kegiatan monitoring.

Hasil proses pemberdayaan yang berwujud pelatihan, adalah adanya kesadaran akan peran penting bank sampah Sejahtera dalam mengelola sampah rumah tangga warga di wilayahnya Adanya kemampuan memecahkan masalah yang berkaitan dengan sampah plastik yang mendominasi sampah dengan teknik ecobricks sampai menjadi produk kreatif mengikuti konsep "3R". Adanya kemampuan menguji dan mendemonstrasikan dengan cara memproduk, menentukan harga, mempromosikan serta memasarkan produk melalui social media.

Hasil proses pemberdayaan yang berwujud pendampingan, adalah adanya peningkatan kreatifitas dari waktu ke waktu, sehingga terbentuk seperangkat furnitur (4 buah stool dan sebuah meja). Diputuskan bahwa seperangkat furnitur ini akan menjadi produk pertama dalam rintisan ecoprenuership. Produk ini telah dipromosikan melalui social media di whatsapp grup Joyotakan Jaya.

Semua tahapan kegiatan dalam Program Kemitraan Masyarakat, mengacu pada konsep dan proses pemberdayaan dengan pendekatan people centered development.

\section{DAFTAR PUSTAKA}

Andriastuti, T.B., Arifin \& Fitria, L. (2019). Potensi Ecobrick Dalam Mengurangi Sampah Plastik Ru Tangga Di Kecamatan Pontianak Barat. Jurnal Teknologi Lingkungan Basah, 07(2), 5563.http://jurnal.untan.ac.id/inde x.php/jmtluntan/article/view/3 
6141.

Fitriani, S \& Asih, H.M. (2019). Metode Full Costing Sebagai Dasar Penentuan Harga Produk Kreasi Sampah Ecobrick. JISI: Jurnal Integrasi Sistem Industri, 6(1), 6569.

http://jurnal.umj.ac.id/index.ph $\mathrm{p} / \mathrm{jisi} \% 0$ Ayang.

Hamid \& Hendrawati. (2018). Manajemen Pemberdayaan Masyarakat. De La Macca. Makasar.

Latipulhayat \& Atip. (2015). Khazanah: Jeremy Bentham. Ilmu Hukum, 2(2), 413-425.

http://jurnal.unpad.ac.id/pjih/a rticle/download/7342/3375.

Mahadiansar, I.K., Sentanu, I.G.E.P.S., \& Aspariyana. (2020). Paradigma Pengembangan Model Pembangunan Nasional Di Indonesia. Jurnal Ilmu Administrasi: Media Pengembangan Ilmu dan Praktek Administrasi, 17(1), 77-92. http:/ /jia.stialanbandung.ac.id/i ndex.php/jia/article/view/550

Mariani, L.P., Meitriana, M.A., \& Zukhri, A. (2014). Penerapan Metode Full Costing Sebagai Dasar Perhitungan HPP Dalam Menentukan Harga Jual Dupa Pada UD Ganesha. Ganesha, 4(3), 1-10.

DOI: http:/ / dx.doi.org/10.23887 /jjpe.v4i1.3312.

Purwaningrum \& Pramiati. (2016). Upaya Mengurangi Timbulan Sampah Plastik Di Lingkungan. Indonesian Journal of Urban and Environmental Technology, 8(2) 141-
149.

DOI: http:/ /dx.doi.org/10.25105

/urbanenvirotech.v8i2.1421.

Purwowibowo, H.K., \& Soelistijono, P.A. (2018). Peningkatan Kapasitas Manusia Sebagai Fokus Dari People Centered Development. Aristo, 6(2), 283-297. http:/ /journal.u mpo.ac.id/index.php/aristo/arist o@u mpo.ac.id.

Rahmadani \& Arif, F. (2020). Upaya Menumbuhkan Kesadaran Masyarakat Dalam Menjaga Kebersihan Lingkungan Melalui Pengelolaan Bank Sampah. CommEdu (Community Education Journal), 3(3), 261-269. DOI: http:/ /dx.doi.org/10.22460 /comm-edu.v3i3.3482.

Rozalena \& Agustin. (2020). Peningkatan Pengetahuan Dan Keterampilan Pengelola Bank Sampah Melalui Sistem Cerdas Komunikasi Pemasaran. JPPM: Jurnal Pendidikan dan Pemberdayaan Masyarakat, 7(1), 89-100. DOI: https://doi.org/10.21831/jp pm.v7i1.32647.

Suhelpi \& Saragih, L. (2020). Analisa Pemasaran Bank Sampah Dengan Pendekatan Analisis SWOT Studi Kasus Pada Bank Sampah Dinas Lingkungan Hidup Kota Pematangsiantar. Manajemen: Jurnal Ekonomi USI, 2(2), 92-102.

Sukimto \& Sekartaji. (2017). Ecobrick: Solusi Cerdas Dan Kreatif Untuk Mengatasi Sampah Plastik. Jurnal Desain Produk (Pengetahuan dan Perancangan Produk), 3(1), 26-34. http://journal.isi.ac.id/index.ph p/PRO/article/view/1735/495. 
Suryani \& Sri, A. (2014). Peran Bank Sampah Dalam Efektivitas Perencanaan Partisipatif ,14(2), 124140.

Pengelolaan Sampah (Studi Kasus Bank Sampah Malang). Jurnal Aspirasi, $\quad$ 5(1), 71-84. DOI: https:// doi.org/10.46807/a spirasi.v5i1.447.

Vigintan, B.R.P. \& Hardiana, A. (2019).

Faktor - Faktor Yang Mempengaruhi Kinerja Bank Sampah Di Kota Surakarta Berdasarkan Persepsi Masyarakat Pengguna Bank Sampah. Jurnal Pembangunan Wilayah dan DOI: https://doi.org/10.1234/re gion.v14i2.22950.

Yuliarini \& Sarah. (2020). Penerapan Metode Variable Costing Dalam Penetapan Harga Pokok Produksi Pada Pelaku Umkm ( Studi Kasus Pada Umkm Alpujabar Yang Tergabung Dalam Rumah Batik Putat Jaya ). Accounting Journal ,02(1), 24-48. https://journal.uwks.ac.id/index .php/liability/article/view/877. 